\title{
A semantic account of mirative evidentials*
}

\author{
Jessica Rett \\ UCLA \\ Sarah E. Murray \\ Cornell University
}

\begin{abstract}
Many if not all evidential languages have a mirative evidential: an indirect evidential that can, in some contexts, mark mirativity (the expression of speaker surprise) instead of indirect evidence. We address several questions posed by this systematic polysemy: What is the affinity between indirect evidence and speaker surprise? What conditions the two interpretations? And how do mirative evidentials relate to other mirative markers? We propose a unified analysis of mirative evidentials where indirect evidentiality and mirativity involve a common epistemic component. A mirative interpretation requires a close temporal proximity between the speech event and the event of the speaker's learning the at-issue content.
\end{abstract}

Keywords: evidentials, exclamation, mirativity, illocutionary mood

\section{Introduction}

The focus of this paper is a type of morpheme we refer to as a 'mirative evidential' (ME). Mirative evidentials mark indirect evidence in some contexts and mirativity in others. We begin by introducing these concepts.

Many languages grammaticize evidentiality, encoding the type of evidence one has for a proposition. The proposition that the evidential marks will be called the 'at-issue proposition' $p$. Languages differ in the types of evidentiality they mark. Cherokee (Iroquoian, North Carolina and Oklahoma), for instance, only distinguishes direct and indirect evidentiality, corresponding roughly to first-hand and non-first-hand evidence (Aikhenvald 2004: 26-7). ${ }^{1}$

* We thank Sam Cumming, Gabe Greenberg, Daniel Gutzmann, Robert Henderson, Natasha Korotkova, Manfred Krifka, Wayne Leman, Mats Rooth, Philippe Schlenker, Roger Schwarzschild, Todd Snider, and Will Starr for their feedback, as well as audiences at CUSP 5 (UCSD), Cornell University and at SALT 23. Sarah would also like to thank her Cheyenne consultants and others she has talked with about Cheyenne for their collaboration and discussion of Cheyenne data.

1 Evidentials are bolded throughout. The glosses of mirative evidentials are underlined (e.g., IND). Other glosses: ASSOC associative, DECL declarative, DEM demonstrative, DIR direct evidential, FEM feminine, IMPF imperfect aspect, IND indirect evidential, LOC locative, MOD agreement for negation, NAR narrative evidential, NEG negation, PST past tense, REFL reflexive marker, REM.PST remote past tense, RPT reportative evidential, SG singular, TOP topic marker, Y/N question particle.

(C)2013 Rett \& Murray 
(1)

a. U-gahnan- $\delta$ ?i.

it-rain-DIR.PST

'It rained (I saw/heard it).' b. U-gahnan-e?i.

it-rain-IND.PST

'It rained (I heard/inferred).'

In Cherokee, a grammatical sentence must contain an evidential marker; these markers are encoded as verbal suffixes. (1a) is formed with a direct evidential, which means the speaker had either first-hand visual or auditory evidence for the at-issue proposition $p$ (i.e., that it rained). The examples in (1b) are formed with an indirect evidential, which means the speaker had something other than first-hand evidence for $p$. Indirect evidence can be a report or the speaker's own inference from a distinct set of affairs. A natural inferential evidence context for (1b) is one in which the speaker woke up, looked outside and saw puddles of water on the ground.

It's been widely observed that evidential languages often have a polysemous marker that in some contexts marks indirect evidence for the at-issue proposition $p$ and in other contexts marks that the speaker found $p$ unexpected or surprising. We use the term 'mirativity' to refer to the expression of speaker surprise across constructions. In the case of mirative evidentials, we will refer to this as the mirative interpretation (cf. the evidential interpretation) of a mirative evidential. The contrast is demonstrated in (2) for Mapudungun (isolate, Chile; Aikhenvald 2004: 200), whose mirative evidential is the reportative evidential.

Aku-rke-y.

arrive-REP-DECL

'S/he arrived (they said).'

'S/he arrived (surprisingly)!'

evidential interpretation mirative interpretation

In this paper, we address several questions raised by mirative evidentials. First, what is the affinity between indirect evidence and mirativity such that this polysemy is found across language families? Second, what conditions the two interpretations of mirative evidentials? And, third, what is the relationship between mirative evidentials and other types of mirative constructions?

In the next section we introduce the phenomenon of mirativity, focusing on how it seems to be manifested outside of evidential markers. In $\S 3$ we'll present several empirical observations about mirative evidentials generally; in $\S 4$ we turn to focus on Cheyenne as a case study. Theoretical preliminaries are introduced in $\S 5$ and in $\S 6$ we present a unified semantic analysis of mirative evidentials.

\section{Mirativity across constructions}

Mirativity is the linguistic encoding of exceeded expectation or surprise on the part of the speaker. We take the semantic contrast between English (3a) and (3b) - 
A semantic account of mirative evidentials

conditioned by intonation - to be all and only one of mirativity.

(3) a. John arrived on time.

b. (Wow, John arrived on time!

Following Rett $(2008,2009,2011)$, we assume that the mirative component of (3b) is an expression of speaker surprise (see also Sadock \& Zwicky 1985; Kaplan 1997; Michaelis 2001; Castroviejo-Miró 2006). It is distinct from assertions of speaker surprise, as in (4), because it is undeniable in discourse, as seen in (5); unembeddable under negation and other sentential operators, as illustrated in (6); and incompatible with other kinds of illocutionary mood, as in (7).

(4) I am surprised that John arrived on time.

(5) A: (Wow,) Those cupcakes are vegan!

B: No, they're vegetarian.

B': \#No, you're not surprised/you knew exactly how incredible it was.

(6) a. (Wow, John didn't arrive on time!

b. Mary said John arrived on time!

(7) Where did John arrive on time!

English (6a) cannot be used to express that the speaker is not surprised that John arrived on time. (6b) can express the speaker's surprise that Mary said John arrived on time; it cannot be used to express Mary (the subject's) surprise that John arrived on time. (7) shows that this mirative marker - English exclamation intonation cannot combine with question intonation. We account for these data by analyzing mirativity as an illocutionary mood.

However, we will have little to say about what exactly mirative markers are expressing. Rett (2011) characterizes them as expressing "that a particular proposition has violated the speaker's expectations." Merin \& Nikolaeva (2008) characterize them as expressing “drastic deviations from the speaker's expectation." Elsewhere mirative markers have been characterized as contributing an expression of surprise. As Rett (2011) notes, mirative constructions are very natural as compliments - as in Wow, what a great apartment you have! - in which case they mean "something like "No matter how high my expectations might have been, what I have just heard exceeded them" (DeLancey 1997: 38)."

One final property of exclamations has, we believe, gone relatively unnoticed in the literature. Their acceptability in a discourse is dependent on the relation between when the speaker learned the at-issue proposition $p$ and the time of utterance. (As Rett (2011) argues, $p$ must also be salient in the discourse context.) The contrast between (8) and (9) illustrates this; despite Sue being surprised in both contexts that 
Bill is driving a new car, her exclamation in (9) is infelicitous because it is uttered relatively late after her learning that he is. This phenomenon, which we refer to as the 'recency restriction' on mirativity, will be further discussed below in Section 3.3.

context: John and Sue watch Bill pull up in a new car.
a. Sue, to John: (Wow, Bill has a new car!
b. John: Yes, how exciting!
context: John and Sue watch Bill pull up in a new car.
a. Sue, to John: I thought that Bill was still driving a Nissan.
b. John: I did too.
c. Sue: \#(Wow,) Bill has a new car!

\section{Mirative evidentials across languages}

In this section we'll report three semantic properties of mirative evidentials (MEs) based on descriptive work on the markers across languages. They are: 1) mirative evidentials are indirect evidentials; 2) mirative evidentials can mark mirativity; and 3) mirative evidentials are subject to the recency restriction.

\subsection{Mirative evidentials are indirect evidentials}

Across languages, the evidential markers that can mark mirativity are indirect (rather than direct) evidentials. They mark narrative, reportative or inferential evidence (or indirect evidence generally) but never first-hand sensory evidence (visual or auditory).

The Cuzco Quechua (Quechuan, Peru) ME can mark evidentiality only when the speaker has hearsay or inferential evidence for the at-issue proposition $p$. Faller (2004: 52) says (10) is "felicitous in a situation in which the speaker finds the pieces of the broken cup, but did not witness the breaking itself."

Q'iru p'aki-ku-sqa-n.

cup break-REFL-IND-DIR

'The cup broke.'

In Udihe (Altaic, Eastern Russia), the evidential interpretation of the ME is acceptable only in contexts in which the speaker has inferential evidence that $p$ (translated as 'it turns out that' and 'apparently'; Nikolaeva \& Tolskaya 2001: 462). In Cheyenne (Plains Algonquian, Montana and Oklahoma), the ME is the narrative evidential (Murray 2010). ${ }^{2}$ On an evidential interpretation, as in (11a), it indicates

2 Forms of the narrative evidential include, for intransitive verbs, -neho for inanimate subjects and 
A semantic account of mirative evidentials

that $p$ is part of a story, typically occurring with the remote past marker. The narrative evidential can also have a mirative interpretation, as in (11b).

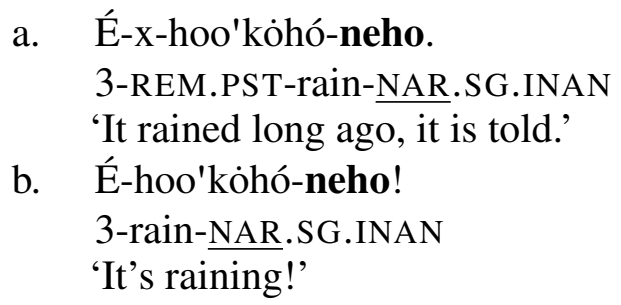

In summary, across languages the evidential interpretaion of the ME indicates that the speaker has indirect evidence for the at-issue proposition $p$. This contrasts with the mirative use, where the speaker can have direct or indirect evidence for $p$, discussed below.

\subsection{Mirative evidentials can mark mirativity}

Mirative evidentials can mark mirativity in a context regardless of what type of evidence the speaker has for the at-issue proposition $p$. Their mirative use is characterized as indicating that the speaker had no "premonitory awareness" that $p$ (Slobin \& Aksu 1982: 196); as signalling "unanticipated/novel information" or an "unprepared mind" (DeLancey 1997; Peterson 2010); or as marking "a more or less spontaneous reaction to a new, salient, often surprising event" (Aikhenvald 2004: 197). They are typical in contexts of discovery, as demonstrated by the Lhasa Tibetan (Tibeto-Burman, China) minimal pair in (12) (DeLancey 1992: 43-44).

$$
\begin{aligned}
& \text { a. Ngar dngul tog=tsam yod. } \\
& \text { I:DAT money some DIR } \\
& \text { 'I have some money.' } \\
& \text { b. Ngar dngul tog=tsam 'dug. } \\
& \text { I:DAT money some IND } \\
& \text { 'I have some money!' }
\end{aligned}
$$

This minimal pair parallels the English one in (3). Lhasa Tibetan (12a) involves a direct evidential, and is natural in any context in which the speaker has first-hand evidence of having money. (12b), in contrast, is formed with a mirative (indirect) evidential marker. It too is acceptable in a context in which the speaker has first-hand evidence of the at-issue proposition $p$, but it is most natural in a context in which the speaker has only just discovered that he has money in his pocket.

-hoo' $o$ for third person singular subjects Leman (2012). 
The mirative interpretation of MEs is available regardless of evidence type (DeLancey 1997, 2001). That is, while mirative interpretations are most naturally elicited in direct-evidence scenarios, they are also possible in indirect-evidence scenarios, including the type of evidence marked by the ME's evidential interpretation.

The ME construction from Tsafiki (Barbacoan, Ecuador) in (13) demonstrates this first point; a natural context for the mirative interpretation is "one in which the speaker heard what he thought was a car approaching. But when he saw it, he realized it was a motorcycle" (Dickinson 2000: 411). ${ }^{3}$

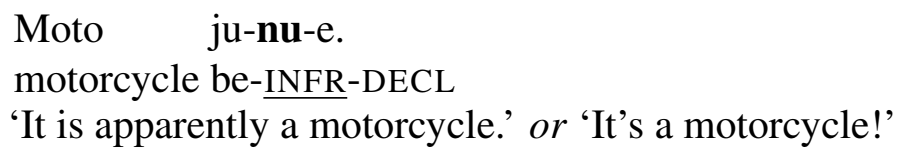

But mirative uses of MEs aren't restricted to direct-evidence contexts. Example (14) from Sunwar (Tibeto-Burman, Nepal) is natural in direct evidence contexts, but "could also be a report of hearsay, but only in circumstances which emphasize the fact that the information was not otherwise available" (DeLancey 1997: 41). ${ }^{4}$

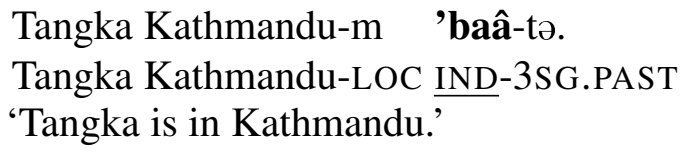

It's often observed that mirative constructions make natural compliments (this use is referred to as a 'pragmatic extension' of MEs in Slobin \& Aksu (1982)). The utterance of (15) in Cuzco Quechua "does not convey that they had thought the addressee was a bad cook" (Faller 2004: 53), or that the speaker had expected the soup to be bad, in a context in which the speaker is complimenting the addressee.

$$
\begin{aligned}
& \text { Lawa-yki-qa sumaq-mi ka-sqa! } \\
& \text { soup-2-TOP nice-DIR be-IND.PST } \\
& \text { 'Your soup is very tasty!' }
\end{aligned}
$$

3 That this form is acceptable in a direct-evidence scenario led Dickinson (and DeLancey before her) to conclude that the inferential evidential ( $n u$ in Tsafiki) is not in fact an evidential. But it's important to separate the two interpretations: the evidential interpretations of MEs impose an evidential restriction, while their mirative interpretations do not.

4 "For example, I suggested to my consultant, as a context for (22), a situation in which the speaker has just learned of Tangka's whereabouts through a phone conversation with someone in Kathmandu, and is reporting it to someone else. He was more comfortable with the mirative form in this context given some elaboration of the context, for example, if the speaker (and probably, though not necessarily, the addressee) had been trying unsuccessfully to ascertain Tangka's whereabouts - a situation which makes as explicit as possible the unavailability of the information to the speaker through any other channel than the one which he bases his report" (DeLancey 1997: 42). 
A semantic account of mirative evidentials

DeLancey (1997: 38) argues that this interpretation "follows directly from the "new knowledge' interpretation."

\subsection{Mirative evidentials and the recency restriction}

We argue that the restriction on the mirative interpretation of MEs is a restriction on all mirative constructions: they are licensed only when the speaker has recently learned the at-issue proposition $p$. This restriction was demonstrated briefly for exclamations in English in (8) and (9). It is also widely regarded in the descriptive literature as a condition for mirative use of MEs. Describing the Cuzco Quechua ME, Faller (2004: 53) says it "would usually be uttered at the time the speaker is perceiving the surprising situation." In Tibeto-Burman languages, the evidential system is encoded in the copular system. Historically, the mirative evidential has been characterized as marking 'new knowledge' (DeLancey 1997, 2001).

The minimal pair from Turkish in (16) shows that the ME $m$ Iş - whose evidential interpretation marks indirect evidence (typically inference or hearsay) - is acceptable in a situation in which the speaker has direct evidence that Kemal came. In this case, the difference between the non-evidential construction in (16a) and the ME construction in (16b) is that the latter (the mirative evidential) is available in a situation in which "[t]he speaker hears someone approach, opens the door, and sees Kemal - a totally unexpected visitor" (Slobin \& Aksu 1982: 187).
a. Kemal gel-di.
Kemal come-PST
b. Kemal gel-mIş.
'Kemal came.'
Kemal come-IND
'Kemal came.'

The mirative interpretation of the Kalasha (Indo-Aryan, Pakistan) ME sentence in (17) is described by DeLancey (1997: 47-8) as natural "when the speaker first sees the work that his friend has accomplished."

Aj'ab krom ka'da-his.

remarkable work do.PST.IMPF-IND.2SG

'You have done a remarkable job!'

In Tsafiki, the ME in (18b) is used, according to Dickinson (2000: 399), "[w]hen you get to the house you realize that you have been there before with Carlos. [...] If you were already aware that you had been there before you would use" the direct evidential (18a).

a. Tse Carlos=be in=te fa-yo-e. $1 \mathrm{FEM}$ Carlos=ASSOC DEM=LOC arrive.here-DIR-DECL 'I've come here (before) with Carlos.' 
b. Carlos=be tse in=te fa-i-e.

Carlos=ASSOC 1FEM DEM=LOC arrive.here-IND-DECL

'I've come here (before) with Carlos! (I just realized it).'

In Cheyenne, an ME is felicitous if the speaker has narrative evidence for the atissue proposition $p$, i.e., if $p$ is part of a story (the evidential use) or if she has recently learned that $p$ (the mirative use). For example, Cheyenne (11b) is infelicitous in a context where the speaker learned that $p$ long before she utters (11b).

\section{Cheyenne: a case study}

In this section, we address the following question: what type of content is the mirative component of mirative evidentials?

Languages seem to differ in the sort of content evidentiality is encoded in. Faller (2002, 2006) argues that one evidential strategy in Cuzco Quechua encodes evidentiality at the speech-act level, but another strategy is modal-like (see also Matthewson, Davis \& Rullmann (2007) for modal analysis of evidentials in St'át'imcets). Murray (2010, to appear) argues that evidentiality in Cheyenne and crosslinguistically is encoded in not-at-issue content, though it may also affect the force of the sentence.

There is a similar debate in the literature on mirativity, broadly construed. Rett $(2009,2011)$ characterizes the mirativity as illocutionary (a speech act in which the speaker simultaneously asserts and expresses surprise that $p$ ). In contrast, Merin \& Nikolaeva (2008); Gutzmann (2011); Chernilovskaya, Condoravdi \& Lauer (2012) argue that mirativity is not-at-issue content or conventional implicature.

We argue that, at least for Cheyenne, the evidential contribution of an ME is not-at-issue content, but the mirative contribution - like mirativity in exclamations is illocutionary or speech-act content.

\subsection{Cheyenne evidentiality is not-at-issue content}

Murray (2010, 2011, to appear) argues that evidentiality in Cheyenne is encoded in not-at-issue content (though evidentials can also affect the force of the sentence). In contrast to at-issue content, evidential content is not directly challengeable, as in (19) for the reportative evidential, nor is it, e.g., embeddable under negation.

a. Méave'ho'eno é-héstảhe-sèstse Mókéé'e. Lame Deer 3-be.from-RPT.3SG Mókéé'e 'Mókéé'e is from Lame Deer, I hear.'

b. É-sáa-hetómèstovè-hane- $\emptyset$. É-sáa-héstàhé-he- $\emptyset \quad$ Méave'ho'eno. 3-neg-be.true-MOD ${ }_{\mathrm{B}}$-DIR 3-neg-be.from-MOD ${ }_{\mathrm{A}}$-DIR Lame Deer 'That's not true. She's not from Lame Deer.' 
A semantic account of mirative evidentials

$$
\begin{aligned}
& \text { c. \#É-sáa-hetómėstovè-hane- } \emptyset \text {. Hovánee'e é-sáa-nè-hé-he- } \emptyset \text {. } \\
& \text { 3-neg-be.true-MOD }{ }_{\mathrm{B}} \text {-DIR nobody 3-neg-that-say-MOD } \mathrm{A}_{\mathrm{A}} \text {-DIR } \\
& \text { Intended: 'That's not true. Nobody said that.' }
\end{aligned}
$$

Evidentials in Cheyenne participate in a phenomenon called 'interrogative flip' (Faller 2002, among others). This is demonstrated in (20) for the evidential interpretation of the narrative evidential (see (11)). In declaratives, evidentiality is speaker-oriented - it reflects the speaker's source of evidence for $p$, as in (19). But in interrogatives like (20), the evidential becomes hearer-oriented, indicating the source of evidence the hearer is expected to have for the answer ( $p$ or $\neg p$ ). For example, Cheyenne (20) asks whether Hawk won, assuming the hearer has narrative evidence for the answer.

$$
\begin{aligned}
& \text { Mó=é-x-hó'tảhevá-hoo'o Aénohe? } \\
& y / n=3-R E M . P S T-w i n-N A R .3 S G ~ H a w k
\end{aligned}
$$

'Given the stories you heard, did Hawk win?'

\subsection{Cheyenne mirativity is illocutionary content}

As discussed above for (11), the mirative evidential in Cheyenne is the narrative evidential. Just like the evidential contribution of the Cheyenne ME, its mirative contribution, too, is undeniable and unembeddable. However, the mirative use patterns with other illocutionary mood or speech-act markers, instead of not-at-issue meanings, in two ways. First, the mirative use doesn't participate in interrogative flip; in questions, the ME cannot receive a mirative interpretation, as in (21).

\section{\%Mó=é-hó' tảhevá-hoo'o Aénohe? $y / n=3$-win-NAR.3SG Hawk Intended: 'Given your surprise, did Hawk win?' / 'Did Hawk really win?!'}

(21) may have an evidential interpretation, similar to (20), but it cannot receive a mirative interpretation (we use \% to mark unavailability of the intended reading).

Second, denial of mirativity has a different semantic status than the denial of the evidential component. Murray $(2010,2011)$ shows that challenging Cheyenne evidentiality results in a sense of contradiction, as shown in (22) (marked with $\#_{\perp}$ ).

$$
\begin{aligned}
& \#_{\perp} \text { É-hó'täheva-sèstse Aénohe naa oha hovánee'e é-sáa-nè-hé-he- } \emptyset \text {. } \\
& \text { 3-win-RPT.3SG Hawk but nobody 3-neg-that-say-MOD }{ }_{\mathrm{A}} \text {-DIR } \\
& \text { Intended: 'Hawk won, it's said, but nobody said that.' }
\end{aligned}
$$

This seems to parallel the behavior of evidential adverbials in English and (other) non-at-issue content, like that encoded in appositives (Potts 2005), as (23) shows. 
a. Allegedly, Roger shoplifts. $\#_{\perp}$ Though no one has ever said so.

b. Gabe, who graduated from Rutgers, teaches at UCLA. $\#_{\perp}$ He never graduated from Rutgers.

This contradiction is arguably distinct from the infelicity associated with denial of speech-act-level content, as in (24). For example, in 'Moore's Paradox' sentences like (24a), the speaker denies a sincerity condition on assertion, not literal content.

a. It's raining, \#but I don't believe it's raining.

b. Does Sue like pizza? ...\#I don't want to know.

English exclamations, too, exhibit Moore's Paradox-like effects, as (25) shows. This supports the claim that mirativity is an illocutionary phenomenon.

(25) a. Gabe arrived on time! ...\#I'm not surprised, I knew he'd be on time.

b. How incredibly early Gabe was for his flight! ...\#I'm not surprised, he arrived exactly when I thought he would.

When the Cheyenne narrative evidential receives a mirative interpretation, denial of the mirative content - in contrast to its evidential interpretation as in (22) - also results in infelicity rather than contradiction. For example, Cheyenne (26) is an expression you could use if you had expected that it would rain and you go outside and see that it is in fact raining. Though both (26) and the mirative construction (11b) are used when it is actually raining, (26) indicates the rain was expected and is infelicitous as a follow up (11b), as in (27).

$$
\begin{aligned}
& \text { Ná-nèšè-héne'ena- } \emptyset \text { tsé-to'sè-hešè-hoo'koho. } \\
& \text { 1-continue-know.s.t-DIR CNJ-going.to-how-rain } \\
& \text { 'I knew it was going to rain.' }
\end{aligned}
$$

$$
\begin{aligned}
& \text { É-hoo'köhó-neho! ...\# Ná-nèšè-héne'ena- } \emptyset \text { tsé-to'sè-hešè-hoo'koho. } \\
& \text { 3-rain-NAR.SG.INAN } \quad \text { 1-continue-know.s.t-DIR CNJ-going.to-how-rain } \\
& \text { Intended: 'It's raining! ... \# I knew it was going to rain.' }
\end{aligned}
$$

To sum up: the Cheyenne mirative evidential is the narrative evidential. Cheyenne evidential markers encode not-at-issue content. Their evidential contribution is unembeddable and undeniable in a particular way: as with English not-at-issue content, their denial results in contradiction. The evidential contribution also participates in interrogative flip: in interrogatives, the evidential is anchored to the addressee, as opposed to the speaker. But while the mirative contribution of the Cheyenne $\mathrm{ME}$ is also unembeddable, it seems to be undeniable in a different way, patterning more with instances of Moore's Paradox than with contradiction. Furthermore, the mirative contribution of the Cheyenne ME does not participate in interrogative flip: 
A semantic account of mirative evidentials

the mirative interpretation is unavailable in questions. These differences lead us to conclude that the evidential use of at least the Cheyenne ME involves not-atissue content, but the mirative use - like intonational mirative markers in English exclamation - involves illocutionary content.

\section{Theoretical preliminaries}

In this section, we introduce the formal mechanisms that underlie two key assumptions of our account. First, the recency restriction, that mirative contexts differ from other contexts in the relative timing of the learning event (the speaker's learning that $p$ ) and the speech event. Second, indirect evidentials and mirative markers have in common that they, in contrast to direct evidentials, relate the at-issue proposition $p$ to some contextually salient set $E$ of epistemically accessible propositions. We begin by discussing some theoretical preliminaries.

\subsection{Mirativity as an illocutionary mood}

The Cheyenne mirative evidential makes two distinct types of semantic contributions. To address this formally, we adopt the encoding of evidentiality as not-at-issue content detailed in Murray (2010, to appear) and the notion of mirativity as illocutionary or speech-act-level content outlined in Rett (2011).

Murray (2010, to appear) argues that all sentences can make three semantic contributions: an at-issue proposition, a not-at-issue restriction (contributed by notat-issue content, if there is any), and an illocutionary relation (contributed by mood). For example, consider English (28a); we will assume that appositives contribute not-at-issue content. The three contributions of (28a) can be informally represented as (28b); for formal implementation see Murray (2010, to appear).

a. Hawk, a champion runner, won (the race yesterday).

b.

\begin{tabular}{|l|l|}
\hline at-issue proposition & $p=\lambda w$. hawk won in $w$ \\
\hline not-at-issue restriction & hawk is a champion runner \\
\hline illocutionary relation & propose to add $p$ to $C G$ \\
\hline
\end{tabular}

These three semantic contributions are distinguished by the kinds of updates they introduce, but are all integrated into the same semantic representation. The atissue proposition is represented by a discourse referent. The not-at-issue restriction directly adds the not-at-issue content to the common ground. The illocutionary relation is treated as an update that structures the context. For assertions, this is the proposal to add the at-issue proposition to the common ground $(C G)$. For polar questions, the context set is partitioned into the semantic answers. Other moods can be analyzed as other kinds of structuring updates. 
Rett (2011) encodes mirativity in an illocutionary operator E-FORCE. She assumes that the speech act of exclamation has as a subcomponent the speech act of assertion. (This characterization of complex speech acts is explored in Vanderveken (1990), which defines this relationship in terms of 'illocutionary entailment'.)

E-FORCE $(p)$, when uttered by $s_{C}$, is appropriate in a context $C$ if $p$ is salient and true in $w_{C}$. When appropriate, $\operatorname{E-FORCE}(p)$ counts as an expression that $s_{C}$ had not expected that $p$.

(Rett 2011: 429)

The result is a semantic characterization of English exclamations in which they denote an at-issue proposition $p$ and simultaneously trigger an act of assertion and an act of expression. Transposing this analysis into the structured representations from Murray (2010, to appear), this can be informally represented as (30).

a. Hawk won (the race yesterday)!

b.

\begin{tabular}{|l|l|}
\hline at-issue proposition & $p=\lambda w$. hawk won in $w$ \\
\hline not-at-issue restriction & $\begin{array}{l}\text { propose to add } p \text { to } C G \\
\text { speaker did not expect that } p\end{array}$ \\
\hline illocutionary relation
\end{tabular}

As mentioned above, Murray (2010, to appear) treats the semantic contribution of mood in terms of how it structures the context. We will do the same for the expressive component of mirativity and revise (30) accordingly.

\subsection{The recency restriction}

We've argued that exclamations ((8) and (9)) and the mirative interpretations of MEs (§3.3) are both subject to the recency restriction. In other words, these mirative interpretations are only available relatively recently after the speaker's learning that $p$. In this section, we'll draw on the recency restriction to condition the two interpretations of MEs.

It seems like the recency restriction cannot be characterized simply in terms of immediate temporal precedence; rather, what counts as recent seems to vary from context to context. In particular, it seems as though a speaker can utter an exclamation like Bill has a new car! at different times to different interlocutors, as long as $p$ is relevant and as long as the time of utterance is the first opportunity the speaker has to express surprise to that interlocutor that $p$.

So instead of characterizing the recency restriction temporally, we characterize it aspectually, in terms of the relationship between the speech event and the 'target state' of the learning event (see also Nikolaeva 1999; Koev 2011). We follow Parsons (1990) in differentiating between permanent result or consequent states on the one 
A semantic account of mirative evidentials

hand and potentially temporary target states on the other.

Parsons (1990: 235) describes the target state of an event of throwing a ball on a roof as the (temporary) effect of the ball being on the roof. Arguably, then, the target state of an individual $x$ learning that $p$ is the (temporary) effect of $p$ on $x$, the change of the state of the speaker's knowledge and expectations. If, as with mirative constructions, the speaker did not expect that $p$, then this effect is something like surprise, and the target state of the learning event $e_{l}$ lasts as long as the speaker's surprise. If, as with the discourse particle alas, the speaker had hoped that $\neg p$, this effect is regret, and the target state of $e_{l}$ lasts as long as the regret does. We will thus characterize the recency restriction as follows:

THE RECENCY RESTRICTION: For an event $e_{s}$ of a speaker $i$ uttering a form with at-issue content $p$, and for the event $e_{l}$ of $i$ learning that $p, e_{s}$ satisfies the recency restriction iff $e_{s} \in \operatorname{TARGET}\left(e_{l}\right)$.

Since we claim that all mirative markers impose a recency restriction on the expression of speaker surprise, we can revise the informal account of English exclamation in (30) as follows.

a. Hawk won (the race yesterday)!

b.

\begin{tabular}{|l|l|}
\hline at-issue proposition & $p=\lambda w$. hawk won in $w$ \\
\hline not-at-issue restriction & \\
\hline illocutionary relation & $\begin{array}{l}\text { propose to add } p \text { to } C G \\
e_{S} \in \operatorname{TARGET}\left(e_{l}\right) \rightarrow \text { speaker did not } \\
\text { expect that } p\end{array}$ \\
\hline
\end{tabular}

This will be revised one final time below in (33).

\subsection{An epistemic component}

Mirative evidentials are, without known exception, indirect evidentials. We claim that indirect evidentials (as opposed to direct) have in common that they relate the at-issue proposition $p$ to some contextually salient set $E$ of epistemically accessible propositions. We'll briefly detail our implementation of this.

Following Rett (2011), we characterize $E$ in terms of expectations instead of knowledge per se, eliminating worries about factivity. We take $E$ to be the set of propositions representing the expectations of an individual $x$, including the propositions $x$ knows and believes about the past, present and future. They are those propositions assigned a prior probability above some standard of credence. Just as an individual's knowledge base can change over time, so can her expectation base, so we anchor each expectation state $E$ to an individual $x$ and a time $t$, written $E_{x}^{t}$. 
We use $E$ to characterize the illocutionary component of exclamation: an exclamation that $p$ amounts to an expression that $p$ was not in the speaker's set of expectations $E$ when the speaker learned that $p$ (the time of the learning event, $\tau\left(e_{l}\right)$ ). We represent this as in (33), revised from (32).

a. Hawk won (the race yesterday)!

b.

\begin{tabular}{|l|l|}
\hline at-issue proposition & $p=\lambda w$. hawk won in $w$ \\
\hline not-at-issue restriction & \\
\hline illocutionary relation & $\begin{array}{l}\text { propose to add } p \text { to } C G \\
e_{s} \in \operatorname{TARGET}\left(e_{l}\right) \rightarrow p \notin E_{i}^{\tau\left(e_{l}\right)}\end{array}$ \\
\hline
\end{tabular}

The illocutionary mood component should be seen as an update of E-FORCE that takes the recency restriction into account. We claim that it is (part of) the contribution of any mirative marker. Though this expressive component does not structure the common ground, as the contribution of the declarative mood does, it can be seen as a type of structuring update, operating instead on a different set of propositions: $E$.

Indirect evidentials reference a set of expectations, too; this is what explains the crosslinguistic association of mirativity and indirect evidentiality. In the case of inferential evidentials, the evidential content relates $p$ to the speaker's set of expectations at some salient time $t$ prior to the learning event. We'll represent the evidential content in this case as $E_{i}^{t} \vDash p$, i.e., $p$ is entailed by the speaker's expectations at $t$. Reportative or narrative evidentials are typically characterized as relating $p$ to some prior speech act; we instead take the position that what's relevant for the evidence source is some third party's (an individual or group of individuals) set of expectations (and that a typically reliable way of determining the content of a third party's $E$ is via their speech). In the case of reportative or narrative evidence, then, the evidential content is $E_{y}^{t} \vDash p$, for an individual $y$ and a salient past time $t$.

Indirect evidentials may restrict the type of $E$ by restricting the individual or temporal arguments of $E$. For instance, a reportative evidential might restrict the individual argument to someone other than the speaker (and the hearer). Our tentative claim here is that mirative evidentials are indirect evidentials that are not lexically restricted in this way. Recall that our goal is a unified analysis of the two interpretations of MEs, the first of which (evidentiality) is encoded in not-at-issue content, and the second of which (mirativity) is encoded in illocutionary content. This assumption will allow the evidential contribution of MEs, in mirative contexts, to be trivial.

\section{The analysis}

In this section, we present a unified semantic account of the polysemy of MEs that draws on our claim that both interpretations reference a salient set of expectations 
A semantic account of mirative evidentials

$E$. We argue that all mirative markers impose something like the recency restriction on the expression of speaker surprise, but that MEs differ in additionally encoding not-at-issue restrictions on $E$.

\subsection{A unified analysis of MEs}

Mirative evidentials are mirative markers that additionally encode evidential, not-atissue content. (34a) represents an informal characterization of the semantics of the Cheyenne ME hoo'o.

a. Hawk won-hoo'o.

b.

\begin{tabular}{|l|l|}
\hline at-issue proposition & $p=\lambda w$. hawk won in $w$ \\
\hline not-at-issue restriction & $E \vDash p$ \\
\hline illocutionary relation & $\begin{array}{l}\text { propose to add } p \text { to } C G \\
e_{s} \in \operatorname{TARGET}\left(e_{l}\right) \rightarrow p \notin E_{i}^{\tau\left(e_{l}\right)}\end{array}$ \\
\hline
\end{tabular}

We'll describe (34) by considering two distinct contexts of utterance. In the first, the speaker learns from a folklore that Hawk won the race long ago. Several years later, he utters (34a). In this case, the $E$ introduced in the evidential, not-at-issue content is valued as the community's $(c)$ set of expectations at that time several years ago $(t)$. In this case, the speech act event $e_{s}$ is quite a bit later than the learning event $e_{l}$, so the utterance fails to satisfy the recency restriction. As a result, the content of the utterance includes: its at-issue meaning (the proposition that Hawk won); its not-at-issue evidential meaning (that the source of information is the community's beliefs circa $t$ ); and its illocutionary meaning, which consists only of assertive force, the proposal to add $p$ to the common ground, because the antecedent of the conditional in (34) failed to hold. The result is in (35b).

a. Hawk won-hoo'o. evidential interpretation

b.

\begin{tabular}{|l|l|}
\hline at-issue proposition & $p=\lambda w$. hawk won in $w$ \\
\hline not-at-issue restriction & $E_{c}^{t} \vDash p$ \\
\hline illocutionary relation & $\begin{array}{l}\text { propose to add } p \text { to } C G \\
e_{S} \in \operatorname{TARGET}\left(e_{l}\right) \rightarrow p \notin E_{i}^{\tau\left(e_{l}\right)}\end{array}$ \\
\hline
\end{tabular}

This account of the evidential use of MEs takes advantage of Rett's (2011) claim that the illocutionary force of mirative constructions includes an expression of surprise that $p$ in addition to an assertion that $p$.

In a second context, the speaker witnesses Hawk winning the race, turns to the hearer, and immediately utters (36a). In this context, the salient $E$ is the speaker's set of expectations. Because the recency restriction is satisfied, the illocutionary content of the speech act is to assert that $p$ and to express that $p$ was not previously in the speaker's expectation set. The result is in (36b). 
b.

\begin{tabular}{|l|l|}
\hline at-issue proposition & $p=\lambda w$. hawk won in $w$ \\
\hline not-at-issue restriction & $E \vDash p$ \\
\hline illocutionary relation & $\begin{array}{l}\text { propose to add } p \text { to } C G \\
e_{s} \in \operatorname{TARGET}\left(e_{l}\right) \rightarrow p \notin E_{i}^{\tau\left(e_{l}\right)}\end{array}$ \\
\hline
\end{tabular}

In this context, the ME contributes no indirect evidential restriction. The question becomes, then, what happens to the not-at-issue restriction encoded in the ME (as demonstrated in (34)). The possible value of $E$ in this 'evidential' meaning is restricted in part by the illocutionary content: it cannot be valued by the speaker's expectations at the time of the learning event. It seems as though, in mirative uses of MEs, this $E$ is instead valued with the speaker's expectations at the time of utterance, or something equally trivial. If this is right, it explains how MEs mediate in the way they do between different meanings encoded in different types of content.

The analysis offered here is one that characterizes the kinship between indirect evidence and mirativity as an epistemic one: for one meaning, a relevant epistemic state $E$ is the source of evidence; in another, it enables an expression of surprise. Our proposal explains the polysemous behavior of MEs via the recency restriction: the temporal relation between the event of the speaker learning that $p$ and the speech event conditions the polysemy.

In the next section we relate our proposal to descriptive observations that the mirative interpretation seems to correlate with present tense and/or imperfect aspect.

\subsection{Connections with tense and aspect}

It is often reported in the descriptive literature on mirative evidentials that the mirative interpretation is significantly more natural in sentences inflected with present tense and imperfect aspect. DeLancey (1997: 39) reports that the mirative interpretation of the Hare (Athabaskan, Canada) ME lõ is "easy to elicit, but only in imperfective clauses." His examples, however, reveal a difference in tense as well.

a. Mary e-wé' ghálayeyĩda lõ.

Mary its-hide work.PRF IND

'Mary worked on hides, I infer/hear.'

b. Mary e-wé' ghálayeyeda lõ.

Mary its-hide work.IMPF IND

'Mary is working on hides!'

We suspect that the connection between mirativity and present tense is a tendency rather than a universal. And we suspect that aspect influences whether an ME receives a mirative or evidential interpretation only insofar as aspect tends to covary 
A semantic account of mirative evidentials

with tense. ${ }^{5}$

The affinity between present-tense content and mirative interpretations seems to hold, across languages, for sentences in either imperfect (e.g., It's raining!, (11b)) or perfect (e.g., I have come here before!) aspect. It is especially clear in Cheyenne, where the ME is the narrative evidential: the evidential use typically occurs with the remote past, while the mirative use typically occurs with present/recent past.

That mirative uses of MEs are most natural with present-tense content is a natural consequence of our theory. We claim that MEs mark indirect evidence unless the event of the speaker learning that $p$ is recent in a relative sense to the utterance that $p$. A speaker is most likely to have direct evidence for an event or result state that is ongoing at the time of utterance (although indirect evidence isn't precluded). If the speaker has direct evidence for an ongoing eventuality, s/he is likely to have recently learned that $p$. So present-tense propositions are more likely to receive mirative interpretations (compare the English We've been robbed! with We were robbed!).

In contrast, if $p$ is in past tense or perfect aspect, we have no reason to assume anything about when the speaker learned that $p$ or what sort of evidence the speaker had that $p$. (For instance, an individual can assert that Napoleon was defeated at Waterloo immediately after learning this, or not.) So while present-tense propositions are likely to satisfy the recency restriction and involve direct evidence - and thus be interpreted miratively - there is no such tendency for propositions in past tense or with perfect aspect.

\section{Conclusions and extensions}

We began this study of mirative evidentials with some crosslinguistic empirical observations: mirativity is polysemous with indirect evidentiality across languages and language families. Mirative constructions, including the mirative uses of mirative

5 This perspective on the data is supported by the following example from Sunwar (Tibeto-Burman, Nepal; DeLancey 1997: 43), where evidentiality is encoded in the copula system. (ia) is formed with a finite, perfective verb, while (ib) is formed with a nominalized verb, which lacks aspect.
a. Kyarša 'sad-a 'baâ-tə.
goat kill-3SG exist-3SG.PAST
'He killed a goat.' (I hear or infer)
b. Kyarša 'sâ̂-šo 'baa-tə.
goat kill-NOM exist-3SG.PAST
'[I saw] he was killing a goat.' (e.g., when I discovered him)

DeLancey (ibid.) describes the influence of aspect: "What we see here is the grammaticization of the pragmatic tendency toward evidential interpretation of new knowledge marking in perfective contexts, and mirative interpretation in imperfect contexts [...]. This could be predicted, since an event that is perfective is typically past, and therefore no longer "new knowledge." 
evidentials, are acceptable only when the speaker has recently learned the at-issue proposition $p$. And the mirative content of MEs - at least in Cheyenne - is, like that of other mirative constructions, encoded at the illocutionary level. We have concluded from these observations that there is a need for a unified account of indirect evidence and mirativity that addresses different levels of meaning as well as the timing of the utterance.

Using Rett's (2011) account of exclamation and Murray's (2010) account of evidentials, we have argued that indirect evidentiality and mirativity have in common that they relate the at-issue proposition $p$ to some salient, contextually-valued set of expectations $E$. Indirect evidentials reference $E$ in not-at-issue content, and mirative markers reference $E$ in illocutionary content. In the case of MEs, $E$ is referenced in two types of content, with the type of interpretation conditioned by whether or not the speaker has recently learned that $p$.

DeLancey (2001) and others have observed that some types of at-issue content are more likely to trigger the mirative interpretations of MEs: $p$ s inflected for second-person, present-tense and imperfect aspect. We've argued that the indirect evidetiality of MEs, combined with the recency restriction, means that MEs inflected in present tense are biased towards mirative interpretations. More work is needed to determine whether or not this explanation generalizes crosslinguistically.

There are many potential connections between this analysis and work done on related areas. The characterization of indirect evidentials as having an epistemic component - the contextually valued set of propositions $E$ - suggests a clear connection with languages whose indirect evidentials behave like epistemic modals (Chafe \& Nichols 1986; Izvorski 1997; de Haan 1999; Faller 2006; Matthewson et al. 2007).

We argue for a close connection between the interpretation of MEs and the tense of the at-issue proposition $p$. This connection may have consequences for languages (like Guaraní; Tupian, South America) whose evidential system is encoded in tense marking (and whose present-tense, inferential marker seems to have a mirative interpretation; Velázquez-Castillo 2013). If there is a secondary connection between mirativity and aspect, as we argue, then there is an intriguing potential connection between our work and languages (like Andean Spanish) whose imperfect aspect marker also marks mirativity (Torres Bustamante 2012), as well as languages whose perfect marker is polysemous with (Turkish; Izvorski 1997) or conflated with (Bulgarian; Koev 2011) an indirect evidential marker. But such extensions will require significantly more investigation into the connection between tense, aspect, and mirative evidentials.

\section{References}

Aikhenvald, Alexandra. 2004. Evidentiality. Oxford University Press. 
A semantic account of mirative evidentials

Castroviejo-Miró, Elena. 2006. Wh-Exclamatives in Catalan. Barcelona: Universitat de Barcelona dissertation.

Chafe, Wallace \& Joanna Nichols. 1986. Evidentiality: The Linguistic Coding of Epistemology. Ablex.

Chernilovskaya, Anna, Cleo Condoravdi \& Sven Lauer. 2012. On the discourse effect of wh-exclamatives. In Nate Arnett \& Ryan Bennett (eds.), 30th West Coast Conference on Formal Linguistics, Cascadilla Press.

DeLancey, Scott. 1992. The historical status of the conjunct/disjunct pattern in Tibeto-Burman. Acta Linguistica Hafniensia 25. 39-62.

DeLancey, Scott. 1997. Mirativity: the grammatical marking of unexpected information. Linguistic Typology 1. 33-52.

DeLancey, Scott. 2001. The mirative and evidentiality. Journal of Pragmatics 33. 369-382.

Dickinson, Connie. 2000. Mirativity in Tsafiki. Studies in Language 24. 379-422.

Faller, Martina. 2002. Semantics and Pragmatics of Evidentials in Cuzco Quechua: Stanford University dissertation.

Faller, Martina. 2004. The deictic core of "non-experienced past" in Cuzco Quechua. Journal of Semantics 21. 45-85.

Faller, Martina. 2006. Evidentiality above and below speech acts. Ms., University of Manchester.

Gutzmann, Daniel. 2011. Expressive modifiers and mixed expressives. In Oliver Bonami \& Patricia Cabredo Hofherr (eds.), Empirical issues in Syntax and Semantics, vol. 8, 123-141.

de Haan, Ferdinand. 1999. Evidentiality and epistemic modality: Setting boundaries. Southwest Journal of Linguistics 18. 83-101.

Izvorski, Roumyana. 1997. The present perfect as an epistemic modal. In Aaron Lawson (ed.), Semantics and Linguistic Theory (SALT) 7, 222-239. CLC.

Kaplan, David. 1997. The meaning of 'ouch' and 'oops'. Ms., UCLA.

Koev, Todor. 2011. Evidentiality and temporal distance learning. In Neil Ashton, Anca Chereches \& David Lutz (eds.), Semantics and Linguistic Theory (SALT) 21, 115-134. CLC.

Leman, Wayne. 2012. A Reference Grammar of the Cheyenne Language. Raleigh, North Carolina: Lulu Press.

Matthewson, Lisa, Henry Davis \& Hotze Rullmann. 2007. Evidentials as epistemic modals: Evidence from St'át'imcets. In Jeroen van Caenenbroeck (ed.), Linguistic Variation Yearbook vol. 7, 201-254. John Benjamins.

Merin, Arthur \& Irina Nikolaeva. 2008. Exclamative as a universal speech act category: a case study in decision-theoretic semantics and typological implications. Ms., University of Konstanz and SOAS London University.

Michaelis, Laura. 2001. Exclamative constructions. In Martin Haspelmath (ed.), 
Language typology and language universals: An international handbook, vol. 2, 1038-1050. De Gruyter.

Murray, Sarah E. 2010. Evidentiality and the structure of speech acts: Rutgers University $\mathrm{PhD}$ Thesis.

Murray, Sarah E. 2011. A Hamblin semantics for evidentials. In Satoshi Ito, Edward Cormany \& David Lutz (eds.), Semantics and Linguistic Theory (SALT) 19 (2009), 324-341. CLC.

Murray, Sarah E. to appear. Varieties of update. Semantics \& Pragmatics.

Nikolaeva, Irina. 1999. The semantics of Northern Khandy evidentials. Journal Societé Finno Ougrinne 88. 131-159.

Nikolaeva, Irina \& Maria Tolskaya. 2001. A Grammar of Udihe. de Gruyter.

Parsons, Terence. 1990. Events in the Semantics of English. MIT Press.

Peterson, Tyler. 2010. Examining the mirative and nonliteral uses of evidentials. In Tyler Peterson \& Uli Sauerland (eds.), Evidence from Evidentials, 129-159. University of British Columbia Working Papers in Linguistics.

Potts, Chris. 2005. The Logic of Conventional Implicature. Oxford University Press.

Rett, Jessica. 2008. Degree modification in natural language: Rutgers University PhD Thesis.

Rett, Jessica. 2009. A degree account of exclamatives. In Tova Friedman \& Satoshi Ito (eds.), Semantics and Linguistic Theory (SALT) 18, 601-618. CLC.

Rett, Jessica. 2011. Exclamatives, degrees and speech acts. Linguistics and Philosophy 34. 411-442.

Sadock, Jerrold \& Arnold Zwicky. 1985. Speech act distinctions in syntax. In Timothy Shopen (ed.), Language Typology and Syntactic Description, Volume 1, Clause Structure, 155-197. Cambridge University Press.

Slobin, Dan \& Ayhan Aksu. 1982. Tense, aspect and modality in the use of the turkish evidential. In Paul Hopper (ed.), Tense-Aspect: Between semantics and pragmatics, 185-200. John Benjamins.

Torres Bustamante, Teresa. 2012. Real tense and real aspect in mirativity. In Anca Chereches (ed.), Semantics and Linguistic Theory (SALT) 22, 347-364. CLC.

Vanderveken, Daniel. 1990. Meaning and Speech Acts. Cambridge University Press. Velázquez-Castillo, Maura. 2013. The deictic nature of Guaraní evidentials: Distance, directionality and perspective. Ms., Colorado State University.

Jessica Rett

3103L Campbell Hall

University of California, Los Angeles

Los Angeles, CA, 90095

rett@ucla.edu
Sarah E. Murray

212 Morrill Hall

Cornell University

Ithaca, NY 14853

sarah.murray@cornell.edu 